○廣江正明 ${ }^{12}$, 長谷川英之 ${ }^{2)}$, 神崎 晶 ${ }^{3)}$, 中村健太郎 ${ }^{4)}$, 上田麻理 ${ }^{5)}$

1) 一般財団法人 小林理学研究所, 2) 富山大学 学術研究部工学系,

3）慶應義塾大学 耳鼻咽喉科, 4) 東京工業大学 科学技術創成研究院,

5）神奈川工科大学 情報学部

\title{
【1.はじめに】
}

$16 \mathrm{kHz} \sim 32 \mathrm{kHz}$ の超高周波音（VHF 音）の場合、音の波長は約 1 2 $\mathrm{cm}$ で頭部や耳介の大きさに比べ て非常に短い。そのため、音源に対する頭部の位置や向きで聴取音圧が変化し、VHF 音の聴こえに大き く影響する。また、耳介の大きさや形状の違い（個人差）がVHF 領域の聴取に影響を及ぼすことも考え られる。VHF 音の曝露影響を正確に把握する上で、耳介を含めた頭部等が VHF 音の伝搬に与える影響を 把握することはとても重要である。そこで本研究では、ダミーヘッド（HATS）を用いて音源に対する頭 部の向きが耳介周りの VHF 領域の音圧に与える影響を調査した ${ }^{[1]}$ 。

\section{【2. 測定結果】}

実験は神奈川工科大の無響室で行った。回転台に載せたHATSの左耳（左耳珠と対輪間）に小型 MEMS マイクを固定した。水平角度 $0^{\circ}$ (音源が顔正面）から $350^{\circ}$ まで時計回りで $10^{\circ}$ ずつ台を回転さ せながら、HATS から距離 $50 \mathrm{~cm}$ の音源から放射した周波数 $10 \mathrm{kHz} 、 15 \mathrm{kHz} 、 18 \mathrm{kHz} 、 20 \mathrm{kHz} 、 22 \mathrm{kHz}$ の 5 つの純音（30 秒間）の各音圧を計測した。HATS 無しの場合（頭部中央のマイク位置）についても 5 つの純音の音圧を計測した。HATS 有・無のレベル差 $\Delta \mathrm{L}$ と回転角度の関係を図 1 に示す。左耳正面が音 源位置の場合（水平角度 $90^{\circ}$ )、HATS 無よりも音圧レベルが高くなる周波数もあるが、逆に低くなる周

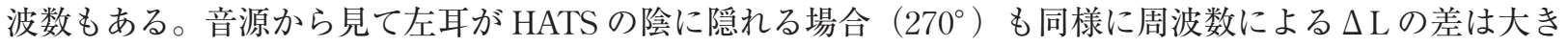
い。音源からの見通しの良し悪し $\left(90^{\circ}\right.$ と $\left.270^{\circ}\right)$ による $\Delta \mathrm{L}$ の差も大きいが、同じ見通しでも周波数によ る $\Delta \mathrm{L}$ の差は大きく、最大で $20 \mathrm{~dB}$ 以上に達していることが確認された。

【3.まとめ】

ダミーヘッドを用いた実験から、耳介を含む頭部等のVHF 音への影響を調査した。耳介周りのVHF 音は音源の見通しだけでなく周波数による差も大きく、同じ音源見通しでも周波数によって最大 $20 \mathrm{~dB}$ 以上も差があることを確認した。今後、耳介や頭部の大きさ・形状が異なる HATS 用いた追実験を行 う予定である。

\section{【文献】}

1. 稲村 他、ダミーヘッド（HATS）を用いたVHF 領域の耳介周りの音響計測、日本音響学会 2021 年 春季研究発表会講演論文集、1-6-12、pp. 493-494、Mar. 2021.

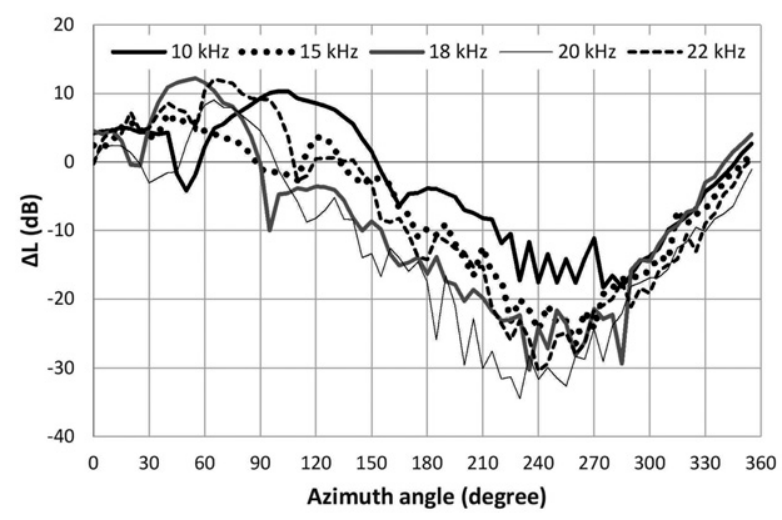

Fig. 1 Relationship between azimuth angle and $\Delta L$ measured by the MEMS microphone. 